\title{
In vitro and in vivo activities of an antitumor peptide HM-3: A special dose-efficacy relationship on an HCT-116 xenograft model in nude mice
}

\author{
SITELBANAT YASSIN ${ }^{1-3^{*}}$, JIALIANG HU ${ }^{1,2^{*}}$, HANMEI XU ${ }^{1,2}, \mathrm{CE} \mathrm{LI}^{1,2}$ and SARRA SETRERRAHMANE ${ }^{1,2}$ \\ ${ }^{1}$ The Engineering Research Center of Peptide Drug Discovery and Development, and \\ ${ }^{2}$ State Key Laboratory of Natural Medicines, Ministry of Education, China Pharmaceutical University, \\ Nanjing, Jiangsu 210009, P.R. China; ${ }^{3}$ Division of Pharmaceutical Microbiology, \\ Department of Pharmaceutics, Faculty of Pharmacy, University of Gezira, \\ Wad Medani 20, Gezira, Sudan
}

Received April 21, 2016; Accepted August 29, 2016

DOI: $10.3892 /$ or.2016.5077

\begin{abstract}
Anti-angiogenesis is an important therapy for cancer treatment. Peptide HM-3 is an integrin antagonist with anti-angiogenic and antitumor activity. Previous research found that HM-3 at an effective dose inhibited tumor growth whereas at higher doses, the inhibitory effect gradually decreased. In the present study, three human tumor cell lines, human colorectal cancer cell (HCT-116) and human hepatic cancer cell (Hep G-2 and SMMC-7721), were selected and their interactions with HM-3 were compared with western blot and flow cytometric assays. The effect of HM-3 on the migration of two tumor cell lines (HCT-116 and Hep G-2) was also evaluated and a bell-shaped dose-efficacy curve was found for both cell lines. Furthermore, in vivo imaging in BALB/c nude mice confirmed that HM-3 had a short half-life and targeted the tumor tissue. Moreover, on an HCT-116 xenograft model in BALB/c nude mice, HM-3 at $3 \mathrm{mg} / \mathrm{kg}$ inhibited tumor growth with an inhibition rate of $71.5 \%$ (by tumor mass) whereas at 12 and $48 \mathrm{mg} / \mathrm{kg}$, the inhibition rates were 59.2 and $36.0 \%$, respectively. Immunohistochemistry analyses found that both sunitinib $(60 \mathrm{mg} / \mathrm{kg})$ and $\mathrm{HM}-3$ (3 and $48 \mathrm{mg} / \mathrm{kg}$ ) decreased microvascular density and increased percent of HIF- $1 \alpha$ and VEGF expressing cells. The present study investigated the effect of tumor microenvironments on the antitumor effect of HM-3 and concluded that HM-3 inhibited angiogenesis
\end{abstract}

Correspondence to: Dr Hanmei $\mathrm{Xu}$, The Engineering Research Center of Peptide Drug Discovery and Development, China Pharmaceutical University, Tongjiaxiang 24, Nanjing, Jiangsu 210009, P.R. China

E-mail: 13913925346@126.com

*Contributed equally

Key words: antitumor, angiogenesis, cell migration, dose-efficacy relation, tumor microenvironment and thereafter tumor growth by directly inhibiting HUVEC migration. The special dose-efficacy curves for antitumor effect and for cell migration inhibition were correlated. The present study also confirmed that the effective dose has to be strictly defined for better clinical applications of anti-angiogenic drugs such as HM-3.

\section{Introduction}

Angiogenesis is an important process during tumor growth (1). As the new blood vessels provide oxygen and nutrients, it is difficult for tumors to grow beyond $1-2 \mathrm{~mm}^{3}$ in size without tumor angiogenesis $(2,3)$. After angiogenesis, the previously dormant tumors start to grow rapidly and begin to invade surrounding tissues or transfer to distant sites. The balance between pro-angiogenic molecules (e.g. VEGF, FGF or EGF) and anti-angiogenic molecules (e.g. angiostatin, endostatin or thrombospondin) decides the time and site where angiogenesis occurs $(4,5)$. Sunitinib is a second-generation multi-targeted receptor tyrosine kinase inhibitor, which has been approved for the treatment of renal cell carcinoma and gastrointestinal stromal tumors $(6,7)$. It inhibits angiogenesis by cutting-off the signal transduction of VEGF that is the main growth factor during tumor angiogenesis. Integrins are the main targets for anti-angiogenic molecules such as endostatin. Being cell adhesion molecules, integrins are involved in a wide range of cell-ECM and cell-cell interactions (8,9-11). As integrin signaling is important for tumor growth, angiogenesis and metastasis, cutting-off integrin signaling is a promising treatment strategy for cancer treatment $(9,11)$. Integrin $\alpha v \beta 3$ is a highly expressed integrin in various tumor cells or activated endothelial cells whereas its expression on the rest of endothelial cells in normal organs remains low (12). Treatment of integrin $\alpha v \beta 3$ with monoclonal antibodies, cyclic RGD peptides or peptidemimetics induced endothelial cell apoptosis (13) and angiogenesis inhibition (11). HM-3 is an RGD modified endostatin-derived synthetic peptide that targets integrin $\alpha v \beta 3$ (14). It inhibited endothelial cell migration and angiogenesis in vitro and inhibited tumor growth in vivo (15). 
Pharmacodynamic studies confirmed that the in vitro and in vivo antitumor activity of HM-3 was dose-dependent in the concentration range of $0.75-3 \mathrm{mg} / \mathrm{kg}$ whereas further increase of HM-3 dosage did not have a higher tumor growth inhibition (16), however, the reason for this has not been investigated.

In the present study, three tumor cell lines were used to determine their expression levels of integrin $\alpha \mathrm{v}, \beta 3, \alpha 5, \beta 1$ subunits by a western blotting technique. Flow cytometric assays were carried out for detection of the adhesion of FITC-HM-3 to the selected tumor cell lines. Furthermore, the in vitro dose-efficacy relationship of HM-3 was investigated by a Transwell cell migration procedure. Moreover, in vivo imaging was carried out for determination of the drug distribution and tumor-targeting effects in BALB/c-nu nude mice. In addition, the in vivo dose-efficacy relationship was investigated in BALB/c-nu nude mice xenografted with HCT-116 cells that were highly inhibited by HM-3 in a cell migration assay. Immunohistochemistry assays for evaluation of expression levels of angiogenesis-related factors, including CD31, HIF-1 $\alpha$ and VEGF, were performed. These studies tried to explain the relationship of tumor microenvironments and the antitumor effect of an angiogenesis inhibitor HM-3. These studies helped to itinerate that HM-3 inhibited angiogenesis and tumor growth by directly inhibiting HUVEC migration and the bell-shaped dose-efficacy relationship should be explained on a molecular level by focusing on the HM-3 special dose-efficacy relationship on HUVEC migration (16).

\section{Materials and methods}

Materials. Sunitinib ( $>99 \%$ purity) was purchased from Melonepharma with a Cas no. 341031-54-7. FITC-HM-3 with 98.3\% purity was obtained from GL Biochem Ltd. (Shanghai, China) (catalog no. 340664). HM-3 with $99.5 \%$ purity was synthesized by GL Biochem Ltd. (catalog no. 140214-2). All laboratory chemicals were of molecular biology grade. Tumor cell lines were obtained from Shanghai Cell Biology Institutes (Shanghai, China).

Cell cultures. HCT-116 colorectal cancer cells were cultured in McCoy's 5A medium containing $50 \mathrm{IU} / \mathrm{ml}$ penicillin, $100 \mu \mathrm{g} / \mathrm{ml}$ streptomycin, 2,200 $\mu \mathrm{g} / \mathrm{ml} \mathrm{NaHCO}{ }_{3}$ and $10 \%(\mathrm{v} / \mathrm{v})$ fetal bovine serum (FBS) (Gibco). SMMC-7721 and Hep G-2 hepatocellular carcinoma cells were cultured in Dulbecco's modified Eagle's medium (DMEM) containing $50 \mathrm{IU} / \mathrm{ml}$ penicillin, $100 \mu \mathrm{g} / \mathrm{ml}$ streptomycin, 2,000 $\mu \mathrm{g} / \mathrm{ml} \mathrm{NaHCO}$ and $10 \%$ (v/v) FBS. All cells were incubated at $37^{\circ} \mathrm{C}$ in a humidified atmosphere of $5 \% \mathrm{CO}_{2}$ (17) while MDA-MB-231 were grown in the absence of $\mathrm{CO}_{2}$. Cells were detached through incubation with trypsin/EDTA and sub-cultured every 2-5 days (18).

Western blot assays. Equal quantities of extracted proteins were loaded on a $10 \%$ SDS-polyacrylamide gel and were electrophoretically separated. The separated proteins in the gel were electrically transferred to a polyvinylidene fluoride (PVDF) membrane (Roche), according to the procedure described by Laemmli (19). Membranes were blocked with 5\% defatted milk in Tris-buffered saline (TBS) with $0.5 \%$ Tween-20 for $30 \mathrm{~min}$. Then, the membrane was incubated with a primary antibody overnight at $4^{\circ} \mathrm{C}$. The first antibodies included rabbit monoclonal anti- $\alpha \mathrm{v}$ integrin (catalog no. 4711S); rabbit monoclonal anti- $\beta 3$ integrin (catalog no. 4702); mouse monoclonal anti- $\beta 1$ integrin (catalog no. 4706S) (Cell Signaling Technology); rabbit polyclonal IgG for $\alpha 5$ integrin (catalog no. 130609) (Santa Cruz Biotechnology). $\beta$-actin was used as the internal control. After incubation with the primary antibody, membranes were washed twice for $1 \mathrm{~min}$ and once for $10 \mathrm{~min}$ with TBS containing $0.5 \%$ Tween-20, and were then incubated with goat anti-rabbit IgG with horseradish peroxidase-conjugated (catalog no. 3223449; Biotech, Manufacturing Co. Ltd.) or goat anti-mouse IgG with horseradish peroxidase-conjugated (catalog no. 422331022; Bioss, Beijing, China) at $25^{\circ} \mathrm{C}$ for $45 \mathrm{~min}$. After incubation with the secondary antibody, membranes were washed three times with TBS with $0.5 \%$ Tween-20 for 10 min. Finally, development and detection of bands were carried out by chemiluminescence $(20,21)$. Briefly, the membranes were incubated with enhanced chemiluminescence detection reagents with SuperSignal West Pico Chemiluminescent Substrate (Pierce) for $5 \mathrm{~min}$, and quantification was carried out using ImageJ software (22).

Flow cytometric assays. The adhesion of FITC-HM-3 to three tumor cell lines was evaluated by the flow cytometry technique, a method described by Janouskova et al (22) with minor modifications. Briefly, the cultured tumor cells were spread on a 6-well plate and were incubated at $37^{\circ} \mathrm{C}$ overnight. After digestion and wash with phosphate-buffered saline (PBS), $1 \mathrm{ml}$ PBS (containing 1\% BSA) was used to resuspend the cells with a density of $1 \times 10^{6}$ cells $/ \mathrm{ml}$. The cells were incubated with $10 \mu \mathrm{l}$ of $1 \mathrm{mg} / \mathrm{ml} \mathrm{FITC-HM-3}$ at $4^{\circ} \mathrm{C}$ for $30 \mathrm{~min}$ in the dark. Then, the cells were collected by centrifugation at $800 \mathrm{rpm}$ for $5 \mathrm{~min}$. After another wash with PBS, the cells were re-suspended in $800 \mu \mathrm{l}$ PBS for flow cytometric detection. The mean fluorescence intensity that characterized drug affinity to integrins $\alpha v \beta 3$ was measured using the FlowJo software version 7.6.1.

Transwell cell migration. During this assay, cells were placed in the upper layer of a cell permeable membrane in presence of $0.5 \%$ BSA and HM-3. The well below the cell permeable membrane was filled with cell medium that contained 5\% FBS. Cell migration was performed for $18 \mathrm{~h}$. Then, migrated cells were stained and counted. The main advantage of this assay was the need of low levels of angiogenic inducers. Images were captured and the migration inhibition rate (MIR) was obtained, following the equation: $\mathrm{MIR} \%=\left(1-\mathrm{N}_{\text {test }} / \mathrm{N}_{\text {control }}\right) \times 100 \%$, in which MIR is the migration inhibition rate, $\mathrm{N}_{\text {test }}$ the number of cells in test samples and $\mathrm{N}_{\text {control }}$ the number of cells in the control sample.

In vivo imaging. In consideration of the above mentioned results in pre-experiment, in vivo image was carried out to identify drug distribution and tumor targeting effect in mice. Two female BALB/c nude mice (6 weeks and $20 \mathrm{~g}$ ) were

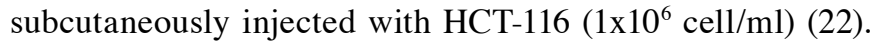
Another two mice were tumor-free as controls. After tumor grew to $300 \mathrm{~mm}^{3}$, detection was performed in which mice were intravenously injected with FITC-HM-3 $(6 \mathrm{mg} / \mathrm{kg})$ and anesthetized with isoflurane inhaler. Images were captured by Caliper IVIS Spectrum system (Caliper Life Sciences, 
Table I. Experimental strategy for tumor inhibitory effect of HM-3.

\begin{tabular}{lrlr}
\hline Group & No. & \multicolumn{1}{c}{ Drug } & Dosage \\
\hline G1 & 12 & Normal saline & $0.2 \mathrm{ml} /$ day/mouse, IV for $21 \mathrm{days}$ \\
G2 & 6 & Sunitinib & $60 \mathrm{mg} / \mathrm{kg}, 0.2 \mathrm{ml} / \mathrm{day} / \mathrm{mouse}, \mathrm{IG}$ for $17 \mathrm{days}$ \\
G3 & 6 & HM-3 & $3 \mathrm{mg} / \mathrm{kg}, 0.2 \mathrm{ml} /$ day $/ \mathrm{mouse}, \mathrm{IV}$ for $21 \mathrm{days}$ \\
G4 & 6 & HM-3 & $12 \mathrm{mg} / \mathrm{kg}, 0.2 \mathrm{ml} /$ day/mouse, IV for $21 \mathrm{days}$ \\
G5 & 6 & HM-3 & $48 \mathrm{mg} / \mathrm{kg}, 0.2 \mathrm{ml} /$ day/mouse, IV for $21 \mathrm{days}$ \\
\hline
\end{tabular}

IG, intra oral gavage; IV, intravenous injection.

Waltham, MA, USA) with excitation wavelength of $490 \mathrm{~nm}$ and emission wavelength of $520 \mathrm{~nm}$. Images were captured at indicated time points.

Dose-efficacy relationship of $H M-3$ on an $H C T-116$ xenograft model in nude mice and the expression levels of angiogenesis-related factors in tumor tissues. Animal experiments were carried out in female BALB/c nude mice (5 weeks and 18-21 g). All mice were subcutaneously injected in the right flank with HCT-116 cells (a density of $1 \times 10^{6} \mathrm{cell} / \mathrm{ml}$ and a total volume of $0.2 \mathrm{ml}$ ). After tumor volume reached $70-100 \mathrm{~mm}^{3}$, mice were put into different groups, which included the negative control group $(n=12)$ that were intravenously injected with $0.2 \mathrm{ml}$ normal saline every day for 21 days; positive controls $(n=6)$ that were fed by oral gavage with $0.2 \mathrm{ml}$ sunitinib $(60 \mathrm{mg} / \mathrm{kg})$ every day for 17 days; mice in the three HM-3 groups $(n=6)$ were intravenously injected with HM-3 (3, 12 or $48 \mathrm{mg} / \mathrm{kg}$ ) every day for 21 days (Table I). During the treatment period tumor volume and body weight of mice were measured every two days for determination of drug efficacy and signs of toxicity. Animals were sacrificed after 21 days from the first injection and the tumor mass was extracted, dissected, blotted on filter paper and immediately weighed. Immunohistochemistry (IHC) was performed where (CD31, HIF-1 $\alpha$ and VEGF) antibodies were used for detection of tumor angiogenesis. Tumors were immediately fixed in $4 \%$ formaldehyde and embedded in paraffin, then, sectioned for immunohistochemical staining of CD31, HIF-1 $\alpha$ and VEGF with rabbit anti-CD31, HIF-1 $\alpha$ and VEGF polyclonal antibodies (Beijing Zhongshan Golden Bridge Biotechnology Co., Ltd.). Briefly, staining for the mentioned angiogenesis factors was performed on sections that were incubated with their specific primary antibodies, biotinylated goat anti-rabbit secondary antibodies, horseradish peroxidase-labeled streptavidin, and the results were visualized with diaminobenzidine (DAB) chromogen. Images were captured under a microscope with a magnification of $\times 200(23)$.

Ethics statement. The experiments involving animals conformed to the ethical standards of China Pharmaceutical University and the care of animals was in accordance with the guidelines of care and use of laboratory animals of China Pharmaceutical University. In vivo imaging was performed under isoflurane anesthesia, and all efforts were carried out to minimize suffering.
Statistical analysis. The data were analyzed using the statistics software SPSS statistics 17.0 (Softonic, San Francisco, CA, USA) and are expressed as mean \pm SD. Statistical significance was assessed using the Student's t-test. $\mathrm{P}<0.05$ was considered statistically significant; $\mathrm{P}<0.01$ was considered statistically very significant.

\section{Results}

Integrin expression and FITC-HM-3 binding to three tumor cell lines. The expression levels of integrin subunit $\alpha \mathrm{v}, \beta 3$, $\alpha 5$ and $\beta 1$ on three human tumor cell lines were detected by western blot assays. As shown in Fig. 1, integrin $\alpha \mathrm{v}$ and $\beta 1$ were expressed on HCT-116, Hep G-2 and SMMC-7721 cells and integrin $\alpha 5$ was expressed on Hep G-2 and SMMC-7721 cells. Integrin $\beta 3$ was expressed on HCT-116 cells (Fig. 1). Only HCT-116 expressed a substantial amount of integrin $\alpha v \beta 3$. Hep G-2 and SMMC-7721 expressed a substantial amount of $\alpha \mathrm{v}$, but trace mount of $\beta 3$, probably they had integrin $\alpha v \beta 5$. All three cell lines obviously expressed integrin subunit $\beta 1$ whereas only Hep G-2 and SMMC-7721 expressed a substantial amount of $\alpha 5$. HCT-116 did express $\alpha 5$ only slightly, probably it expressed other integrin subunits as $\beta 1$ subunit can combine with various $\alpha$ subunits. These results were in line with a previous study (24). Similar study was performed to detect the expression levels of integrin subunits on HUVECs and other human tumor cell lines (A549, MCF-7, HeLa, BEL-7402, MGC-803, HT-29, MDA-MB-231 and U87). Various cells (e.g. A549, MCF-7 and HeLa) expressed high levels of integrin $\alpha v \beta 3$ and $\alpha 5 \beta 1$ whereas HT-29 expressed low levels of integrin $\alpha v \beta 3$ and $\alpha 5 \beta 1$ (data not shown). This difference in integrin expression levels may influence the antitumor effect of anti-angiogenic reagents that use integrins as targets.

In the flow cytometric assays, the fluorescence of cells in the control group that were treated with free FITC molecules was used to define the 'gate' and $99.7 \%$ cells with autofluorescence were included in this gate (Fig. 2A). After FITC-HM-3 incubation, an average of $85.9 \%$ of HCT-116 cells bound with FITC-HM-3, the fluorescence shifted rightward and out of the gate (three tests in Fig. 2B-D). HCT-116 cells displayed high adhesion with FITC-HM-3 and this correlated to its high expression of integrins $\alpha v \beta 3$ (Fig. 1) as integrin $\alpha v \beta 3$ is a target for HM-3. Similar studies were performed for Hep G-2 and SMMC-7721. SMMC-7721 appeared to possess very low adherence with FITC-HM-3 (10.3\%) which was 21 times 


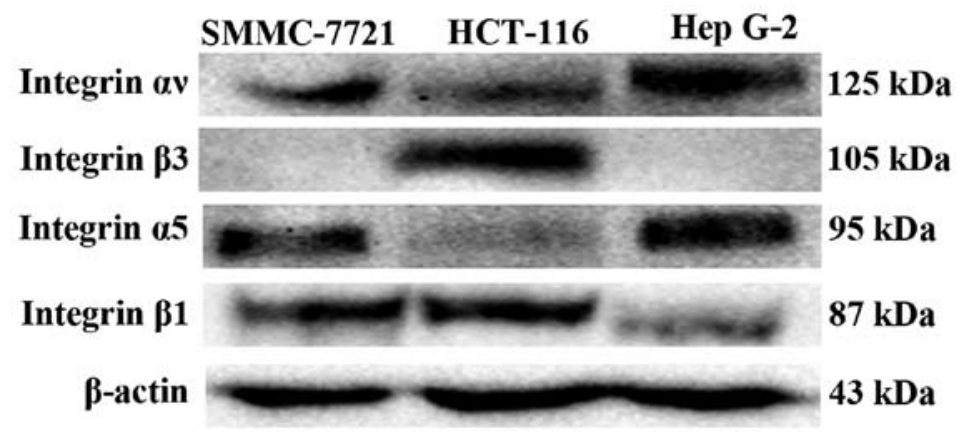

Figure 1. Expression of integrin $\alpha \mathrm{v}, \beta 3, \alpha 5, \beta 1$ subunits on three human tumor cell lines. Protein bands were probed by monoclonal anti-rabbit and goat anti-rabbit antibodies.
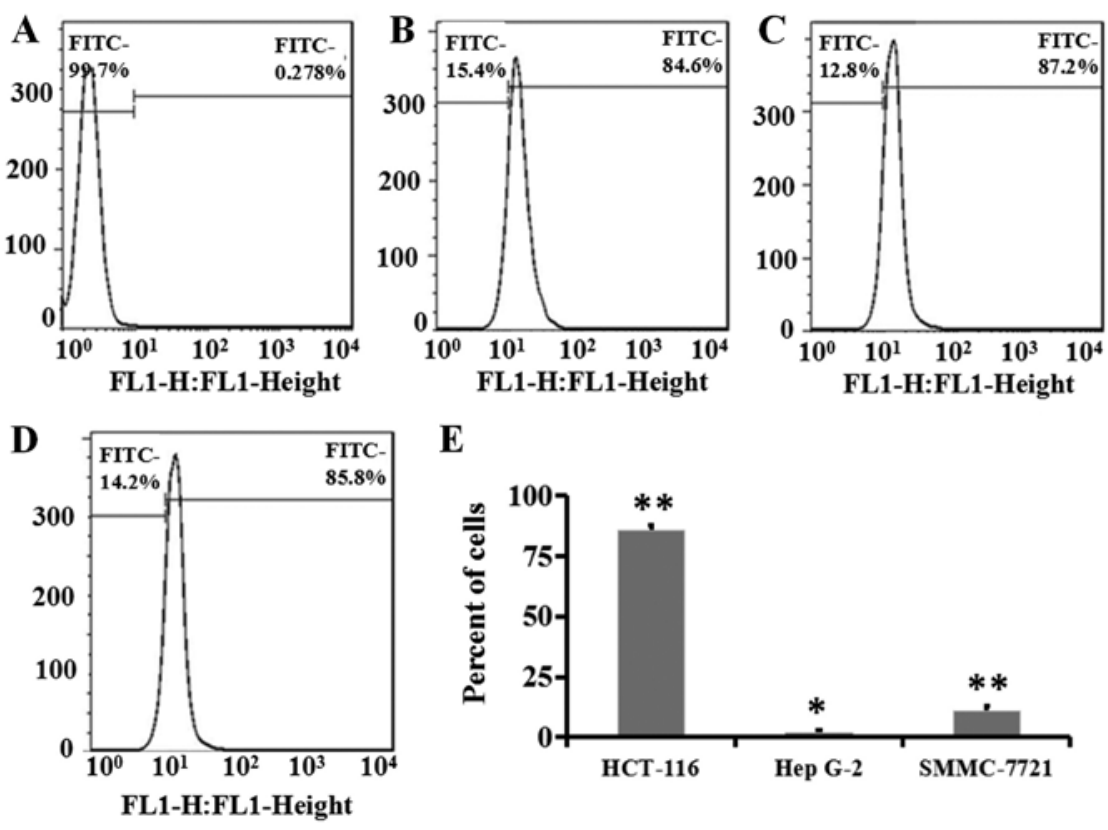

$\mathbf{E}$

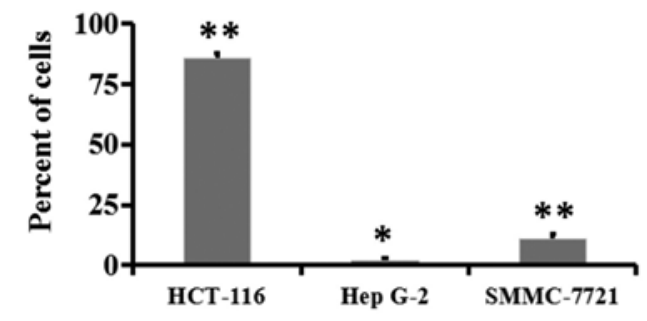

Figure 2. Adhesion levels of FITC-HM-3 on HCT-116 cells. The tumor cells were incubated with $10 \mu \mathrm{g} / \mathrm{ml} \mathrm{FITC-HM-3}$ at $4^{\circ} \mathrm{C}$ for 30 min in the dark before detection. The mean fluorescence intensity that characterized drug affinity to integrins $\alpha v \beta 3$ was measured using FlowJo software version 7.6.1. (A) Flow cytometry graph for cells in the control group. Cells (99.6\%) were gated as autofluorescence. (B-D) Three tests for the fluorescence of cells after incubation with FITC-HM-3 under the same conditions. (E) Percent of cells whose fluorescence signal has moved out of the 'gate' after incubation with FITC-HM-3. Three cell lines, HCT-116, Hep G-2 and SMMC-7721, were compared.

compared to the control $(0.5 \%)$, whereas Hep $\mathrm{G}-2$ displayed a $1.2 \%$ binding with FITC-HM-3 that was approximately four times the control cells $(0.3 \%)$ (Fig. $2 \mathrm{E})$. As these two cell lines expressed high levels of integrin $\alpha 5 \beta 1$, this result confirmed that HM-3 bound with a high affinity to integrin $\alpha v \beta 3$, but not to $\alpha 5 \beta 1$ (25). The present study demonstrated that the three tumor cells varied in their expression levels of integrin subunits and in their capacity to adhere with FITC-HM-3.

HM-3 inhibits the migration of HCT-116 and Hep G-2 cells. Cell proliferation and migration are both important procedures during angiogenesis. A previous study found that HM-3 did not have inhibitory effect on the proliferation of HUVECs, HCT-116 and Hep G-2 cells (data not shown). The inhibitory effect of HM-3 in the migration of HCT-116 and Hep G-2 cells was evaluated in the present study. The Transwell assay is commonly used to evaluate the migratory response of endothelial cells or cancer cells to angiogenic inducers or inhibitors (26). The regulatory effect of HM-3 at low or high doses on the migration of two different tumor cell lines (HCT-116 and Hep G-2) was investigated. Cells were chosen based on their high and low affinity with integrins in the flow cytometric assays (Fig. 2E). The positive control sunitinib was chosen based on its broad spectrum effect in tumor growth, angiogenesis and metastasis and its inhibition of multiple receptor tyrosine kinases (RTKs) (27). Typical images of migrated HCT-116 cells under different conditions are shown in Fig. 3A-G. HM-3 at a concentration of $2 \mu \mathrm{g} /$ $\mathrm{ml}$ displayed high inhibition of HCT-116 migration with a cell migration number of 159 cells, while the cell migration number in the negative control group was 585 cells (Fig. 3H). The inhibition rates of $2 \mu \mathrm{g} / \mathrm{ml} \mathrm{HM}-3$ in the migration of HCT-116 cells was $72.8 \%$ (Fig. 3I). The inhibition rate (MIR) of sunitinib at 0.015 and $2 \mathrm{ng} / \mathrm{ml}$ were 35.2 and $47.4 \%$, respectively (Fig. 3I). Furthermore, HM-3 showed lower inhibitory effects in Hep G-2 migration compared 

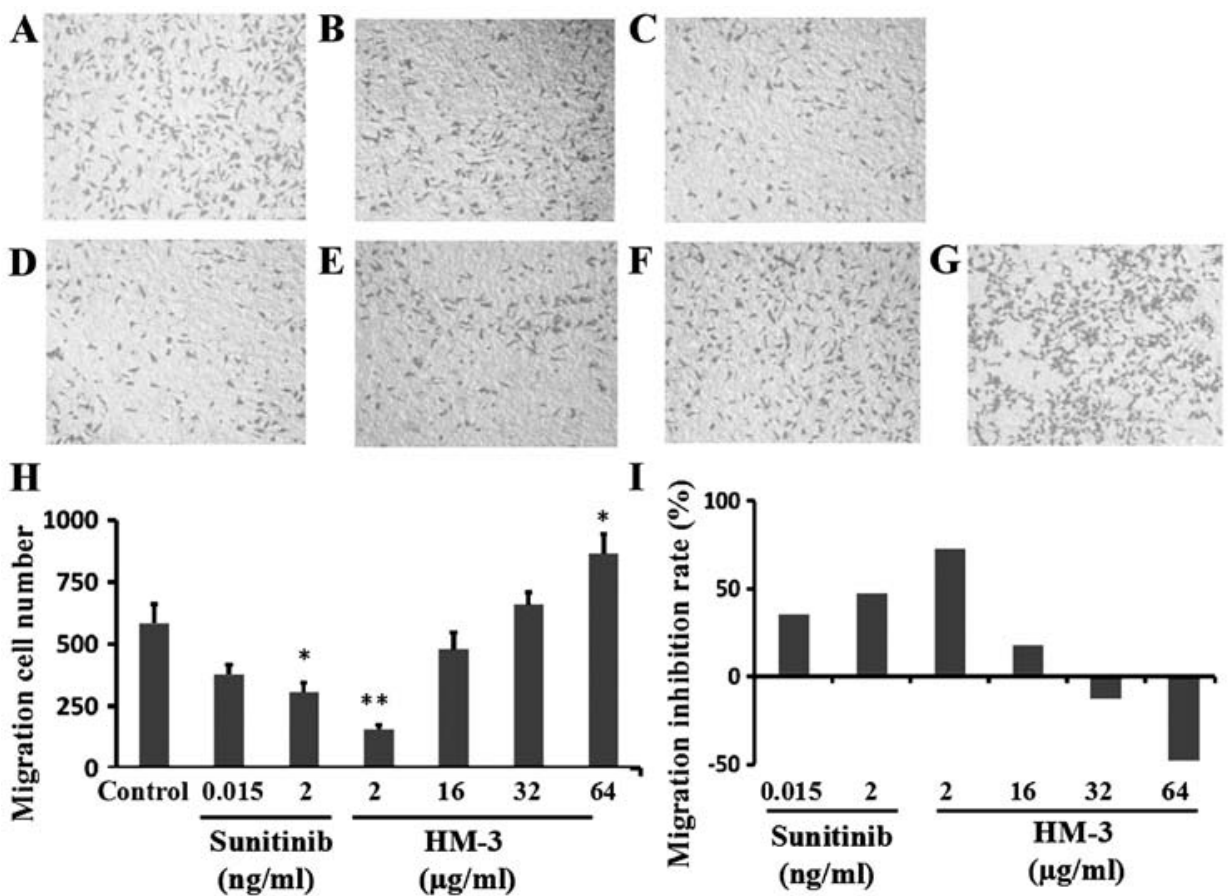

Figure 3. Inhibitory effect of HM-3 and sunitinib on the migration of HCT-116 cells. (A-G) Representative images for migrated cells in each group. G1, control; G2, sunitinib 0.015 ng/ml; G3, sunitinib 2 ng/ml; G4, HM-3 $2 \mu \mathrm{g} / \mathrm{ml}$; G5, HM-3 $16 \mu \mathrm{g} / \mathrm{ml}$; G6, HM-3 $32 \mu \mathrm{g} / \mathrm{ml}$; and G7, HM-3 $64 \mu \mathrm{g} / \mathrm{ml}$. (H) Migrating cell number of each group. (I) Migration inhibition rate for each group. Mean $\pm \mathrm{SD},{ }^{*} \mathrm{P}<0.05$ and ${ }^{* * *} \mathrm{P}<0.01$, compared with the control group.
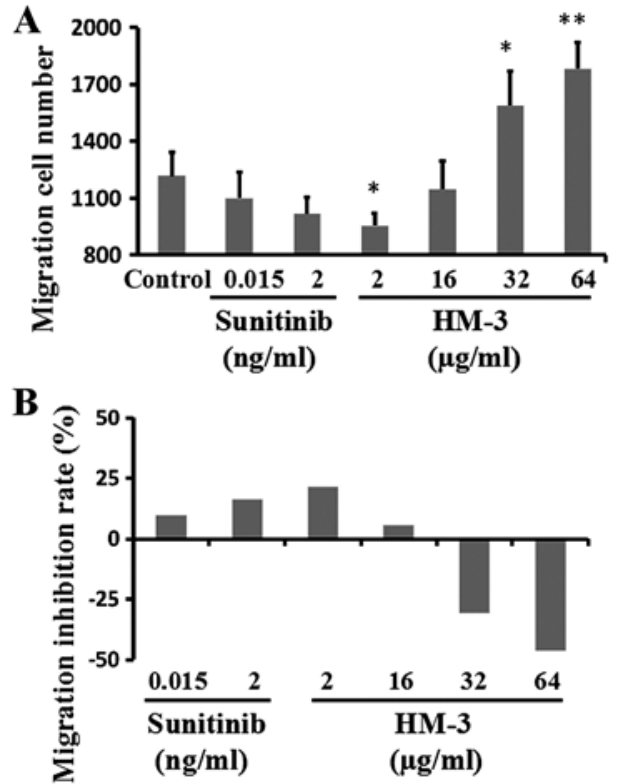

Figure 4. Inhibitory effect of HM-3 and sunitinib on the migration of Hep G-2 cells. (A) Migrating cell number of each group. (B) Migration inhibition rate for each group. G1, control; G2, sunitinib $0.015 \mathrm{ng} / \mathrm{ml}$; G3, sunitinib $2 \mathrm{ng} / \mathrm{ml}$; G4, HM-3 $2 \mu \mathrm{g} / \mathrm{ml}$; G5, HM-3 $16 \mu \mathrm{g} / \mathrm{ml}$; G6, HM-3 $32 \mu \mathrm{g} / \mathrm{ml}$; and G7, HM-3 $64 \mu \mathrm{g} / \mathrm{ml}$. Mean $\pm \mathrm{SD},{ }^{*} \mathrm{P}<0.05$ and ${ }^{* *} \mathrm{P}<0.01$, compared with the control group.

with HCT-116 migration at the corresponding concentrations, e.g. the inhibition rate by HM-3 at $2 \mu \mathrm{g} / \mathrm{ml}$ and sunitinib at $2 \mathrm{ng} / \mathrm{ml}$ were 21.6 and $7.9 \%$, respectively (Fig. 4). However, both HM-3 and sunitinib showed a similar dose-efficacy relationship in inhibition of HCT-116 and Hep G-2 migration (Figs. 3I and 4B). These cell migration results were in line with the above presented western blot results (Fig. 1) and flow cytometry results (Fig. 2E). The inhibition of cell migration by HM-3 was also performed for HUVECs (16) and HM-3 showed a similar dose-efficacy relationship. At $8 \mu \mathrm{g} / \mathrm{ml}$, HM-3 inhibited HUVEC migration with an inhibition rate of $67.0 \%$ whereas at $32 \mu \mathrm{g} / \mathrm{ml} \mathrm{HM}-3$ promoted HUVEC migration with a promotion rate of $10.0 \%$.

As HCT-116 cells showed high integrin expression, high FITC-HM-3 binding and highly inhibitory effect in cell migration by HM-3, this cell line was selected for further in vivo study.

In vivo imaging. Being a peptide, $\mathrm{HM}-3$ is prone to be degraded by in vivo proteases $(14,28)$. The in vivo half-life of HM-3 in rat is only $27 \mathrm{~min}$ (28). To assess the kinetics of HM-3 in vivo and also the distribution of HM-3 in HCT-116 tumor-bearing and tumor-free mice, FITC-HM-3 was intravenously injected and the fluorescence signal was detected at various time points. Within 10 min of the injections, FITC-HM-3 appeared to be widely distributed in different tissues, including the GIT, breast, limbs, lung and also in the tumor mass (Fig. 5A and B). The signal for FITC-HM-3 in tumor-free mice decreased quickly and at the time point of $20 \mathrm{~min}$, the signal substantially decreased (Fig. 5B). However, at $20 \mathrm{~min}$, the signals in HCT-116 tumor-bearing mice were still high (Fig. 5A). At $28 \mathrm{~min}$, there was still obvious signal for FITC-HM-3 and the signal existed in the position of tumor mass (Fig. 5A). These results confirmed that HM-3 had a short in vivo half-life and also it targeted tumor tissue in vivo.

In vivo dose-efficacy relationship of HM-3. In vivo doseefficacy relationship of HM-3 was evaluated on the HCT-116 
A

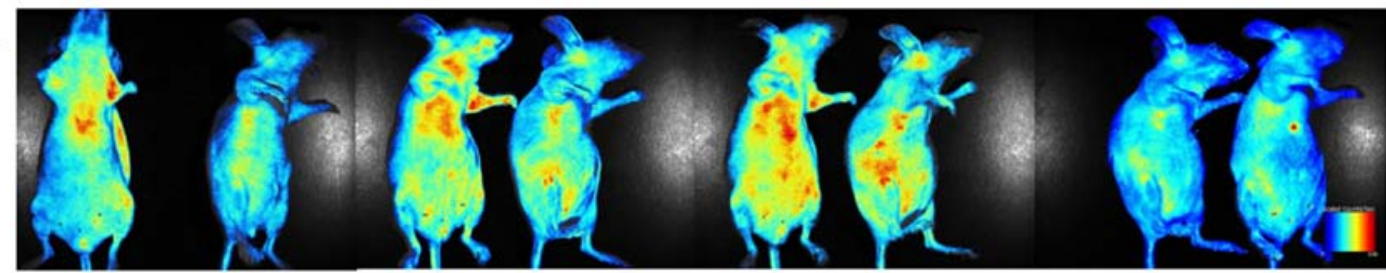

$10 \mathrm{~min}$ $15 \mathrm{~min}$

$20 \mathrm{~min}$

28 min

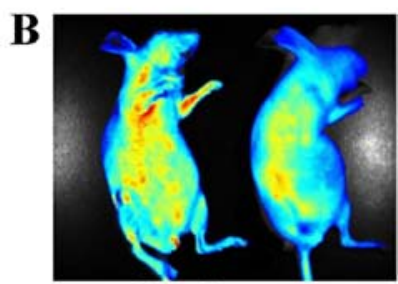

5 min

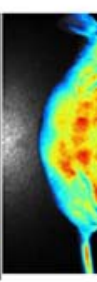

10 min

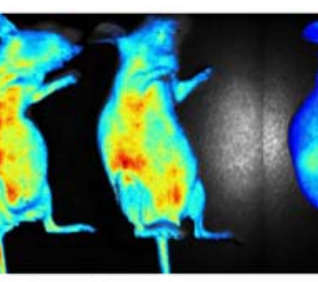

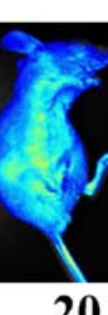

20 min

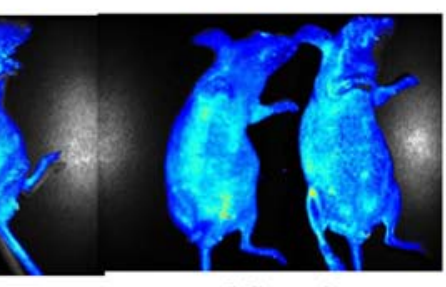

28 min

Figure 5. In vivo imaging for kinetics, tissue distribution and tumor targeting of FITC-HM-3 in BALB/c nude mice. (A) Imaging of in vivo FITC-HM-3 at different time points in nude mice bearing HCT-116 tumor of $\sim 300 \mathrm{~mm}^{3}$ in the right flank. (B) Imaging of in vivo FITC-HM-3 at different time points in tumor-free mice.

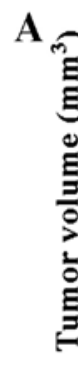

C
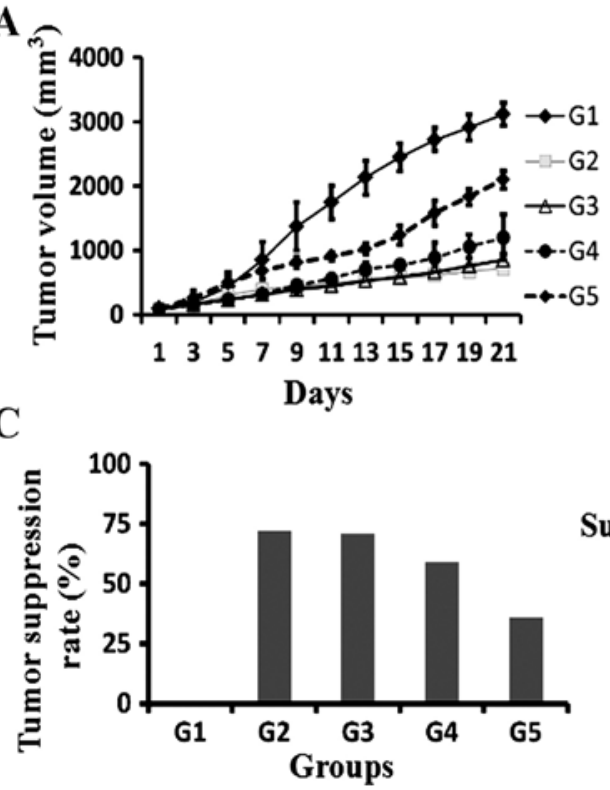

B 잉

D
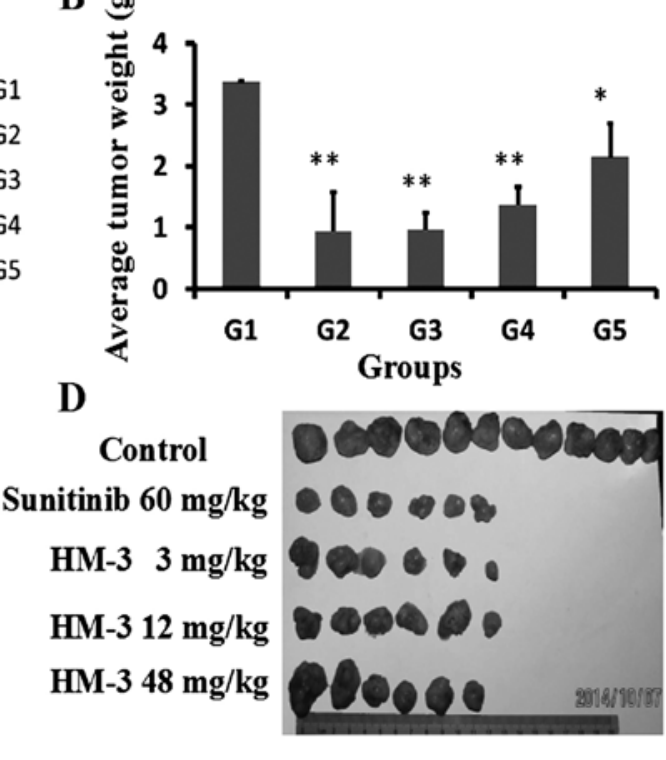

Figure 6. Dose-efficacy of HM-3 on the growth of HCT-116 in nude mice. (A) tumor volume vs. time graph during drug treatment. G1, control (normal saline); G2, sunitinib (60 mg/kg); G3, HM-3 (3 mg/kg); G4, HM-3 (12 mg/kg); G5, HM-3 (48 mg/kg). The above data are mean \pm SD, which represented the average volume of each group. ${ }^{*} \mathrm{P}<0.05$ and ${ }^{* *} \mathrm{P}<0.01$, compared with the control group. (B) Average tumor weight of the tumor tissues from the above mentioned groups. (C) The inhibition rate calculated by tumor weights. (D) Images of the tumor tissues dissected from mice in different groups.

xenograft model in nude mice. The grouping and drug treatment strategies are shown in Table I. During the drug treatment period, tumor volumes (Fig. 6) and mouse weight in different groups (data not shown) were measured every two days. At the initiation of therapy the tumor volume ranged between 75 and $100 \mathrm{~mm}^{3}$. The positive control sunitinib $(60 \mathrm{mg} / \mathrm{kg})$ was daily administered by intra oral gavage for 17 days. Sunitinib at this dose inhibited tumor growth (Fig. 6A) with an inhibition rate of $72.0 \%$ on day 21 (Fig. 6B and C). HM-3 at $3 \mathrm{mg} / \mathrm{kg}$ also showed inhibition with a tumor volume inhibition rate of $74.0 \%$ on day 21 (Fig. 6A) and a tumor mass inhibition rate of $71.5 \%$ (Fig. 6B and C). However, HM-3 did not show a dosedependent inhibition of tumor growth. At a dose of $12 \mathrm{mg} /$ $\mathrm{kg}$, HM-3 showed a tumor volume inhibition of $61.9 \%$ and a tumor mass inhibition of 59.2\% (Fig. 6). At $48 \mathrm{mg} / \mathrm{kg}$, HM-3 showed a tumor volume inhibition of $17.9 \%$ and tumor mass inhibition of $36.0 \%$ (Fig. 6). Data in the present study are in accordance with the previous study. In a previous study, on an SMMC-7721 xenograft model in nude mice, HM-3 at a dose of 1.5 or $3 \mathrm{mg} / \mathrm{kg}$ showed a high tumor growth inhibition with inhibition rates of 57.4 and $53.0 \%$. However, with increase of HM-3 dosage, the inhibition rate decreased gradually and at $24 \mathrm{mg} / \mathrm{kg}$, the inhibition rate was only $9.5 \%$ (16).

HM-3 was not a cytotoxic reagent and during the animal experiment, even the high dose of HM-3 had no sign of toxicity as $100 \%$ of the mice survived in the tested groups until sacri- 
$\mathbf{A}$

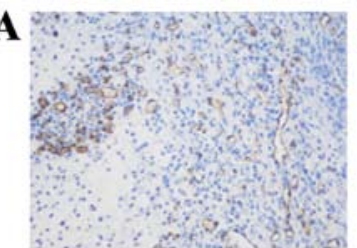

C

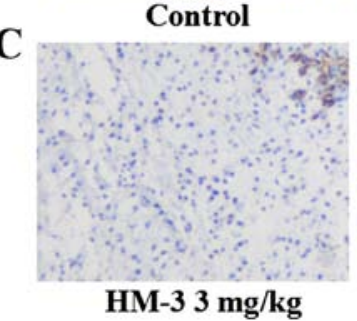

$\mathbf{E}$

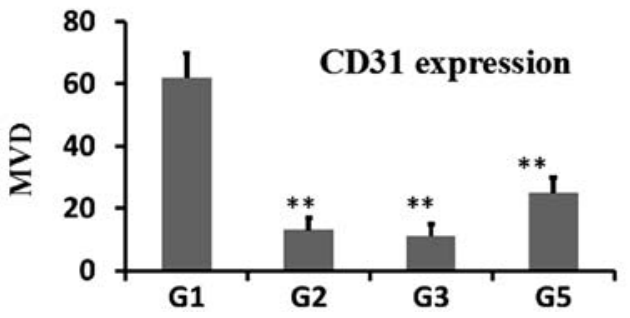

Figure 7. Immunohistochemical analysis of CD31 on the sections of tumor tissues from different groups. (A) Typical image for section from the control group. (B) Typical image for section from sunitinib $(60 \mathrm{mg} / \mathrm{kg})$ treatment group. (C) Typical image for section from HM-3 (3 $\mathrm{mg} / \mathrm{kg})$ treatment group. (D) Typical image for section from HM-3 (48 mg/kg) treatmen group. (E) Comparison of MVD of different groups by counting CD31 positive microvessels. Mean $\pm \mathrm{SD},{ }^{* *} \mathrm{P}<0.01$, compared with the control group.

ficed for tumor extraction. The present study agreed with a previous (20) declaring that HM-3 had no apparent toxic effect on the animals.

Immunohistochemstry analysis of expression of angiogenesis factors. IHC analysis of CD31 (Fig. 7), VEGF (Fig. 8) and HIF-1 $\alpha$ (Fig. 9) was performed to evaluate the expression levels of these angiogenesis-related factors in HCT-116 tumors. Typical images for each experimental condition are presented as panels A-D in Figs. 7-9. In Fig. 7, microvascular density (MVD) of the tumor tissue from the control group was 62.2 in average whereas those for sunitinib $(60 \mathrm{mg} / \mathrm{kg})$ group and HM-3 $(3 \mathrm{mg} / \mathrm{kg})$ group were 12.8 and 11.0, demonstrating that these two anti-angiogenic reagents, though with different working mechanisms, can substantially inhibit tumor angiogenesis during tumor growth (Fig. 7E). The MVD of the tumor tissue from HM-3 (48 mg/kg) group was 25.8, showing a decreased anti-angiogenic effect of HM-3 at this dose (Fig. 7E). This is also in line with the tumor growth inhibition experiments (Fig. 6). In Fig. 8, percent of cells expressing VEGF were counted after staining of VEGF-expressing cells immunohistochemically. On average $20.3 \%$ of total cells were positively stained on the sections from control group tumors. On the sections from sunitinib $(60 \mathrm{mg} / \mathrm{kg})$ and HM-3 $(3 \mathrm{mg} / \mathrm{kg})$ groups, the percent of positively stained cells were 29.8 and 28.2 . Similarly, $25.1 \%$ of cells were positively stained on the sections from $\mathrm{HM}-3(48 \mathrm{mg} / \mathrm{kg})$ group (Fig. 8E). This indicates that the anti-angiogenic effect
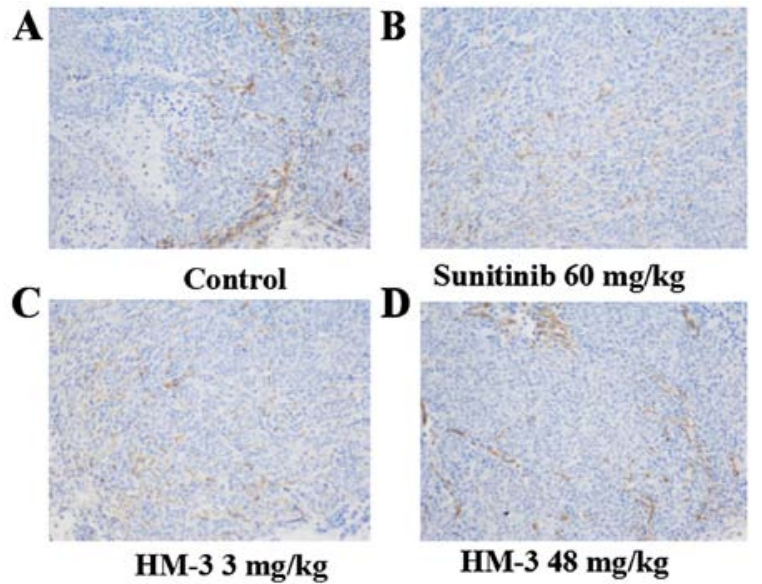

HM-3 $48 \mathrm{mg} / \mathrm{kg}$

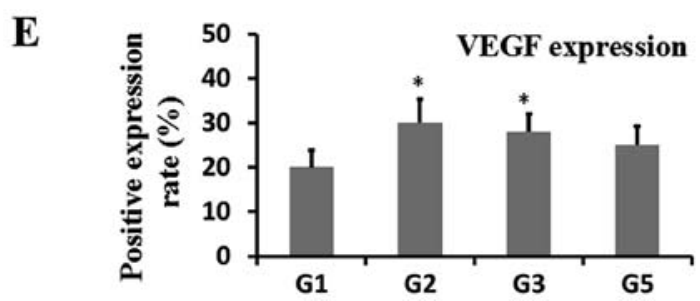

Figure 8. Percent of VEGF expressing cells on the sections of tumor tissues from different groups. (A) Typical image for section from the control group. (B) Typical image for section from sunitinib $(60 \mathrm{mg} / \mathrm{kg})$ treatment group. (C) Typical image for section from HM-3 $(3 \mathrm{mg} / \mathrm{kg})$ treatment group. (D) Typical image for section from HM-3 $(48 \mathrm{mg} / \mathrm{kg})$ treatment group. (E) Comparison of the percent of VEGF-staining positive cells in different groups. Mean $\pm \mathrm{SD},{ }^{*} \mathrm{P}<0.05$, compared with the control group.
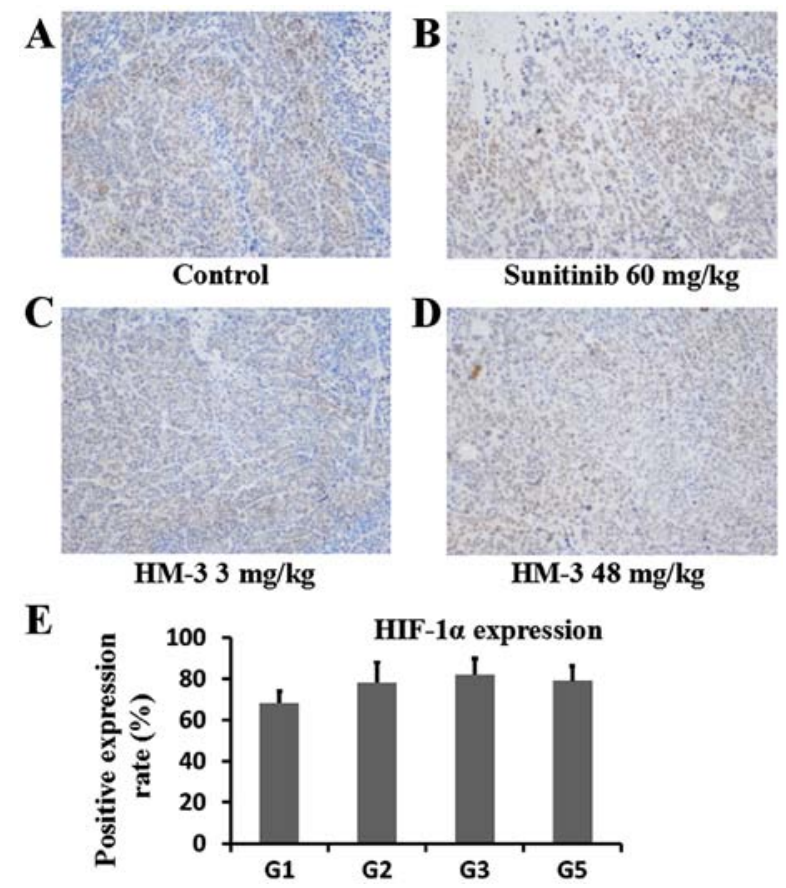

Figure 9. Percent of HIF-1 $\alpha$ expressing cells on the sections of tumor tissues from different groups. (A) Typical image for section from the control group. (B) Typical image for section from sunitinib $(60 \mathrm{mg} / \mathrm{kg})$ treatment group. (C) Typical image for section from HM-3 (3 mg/kg) treatment group. (D) Typical image for section from HM-3 $(48 \mathrm{mg} / \mathrm{kg})$ treatment group. (E) Comparison of the percent of HIF-1 $\alpha$ staining-positive cells in different groups. Mean $\pm \mathrm{SD},{ }^{*} \mathrm{P}<0.05$ and ${ }^{* *} \mathrm{P}<0.01$, compared with the control group. 
of HM-3 was not due to the deceased levels of growth factors such as VEGF, but to a direct inhibitory effect of HM-3 on HUVEC migration, which is an important procedure during angiogenesis. Similarly, sunitinib inhibited angiogenesis since it can 'cut-off' the signal transduction pathway of VEGFR2, which is the main VEGF receptor during angiogenesis, and so higher VEGF levels in the sunitinib $(60 \mathrm{mg} / \mathrm{kg})$ group did not increase angiogenesis. In Fig. 9, percent of cells positively stained with HIF-1 $\alpha$ were counted after probing of sections from different groups with anti-HIF-1 $\alpha$ antibody and staining. On the sections from control group tumors, an average of $67.9 \%$ cells were positively stained whereas for the sections from sunitinib (60 mg/kg) group, HM-3 (3 mg/kg) and HM-3 $(48 \mathrm{mg} / \mathrm{kg}$ ) groups, the percent of positively stained cells were 78.5, 82.3 and 79.1 (Fig. 9E). This result indicated that with the decrease of blood vessel density compared with the control group, the tumors of the drug treatment groups all had a higher degree of hypoxia. The higher hypoxia state made the cells in tumor mass express higher levels of HIF-1 $\alpha$ and thereafter higher levels of VEGF.

\section{Discussion}

In the present study, it was found that, of the three human tumor cell lines HCT-116, Hep G-2 and SMMC-7721, only HCT-116 expressed a high level of integrin $\alpha v \beta 3$. In addition, this cell bound with FITC-HM-3 at a high level in a flow cytometric assay. Furthermore, HM-3 efficiently inhibited HCT-116 cell migration in a Transwell assay. In addition, this inhibitory effect was stronger than its inhibition of Hep G-2 migration under the same concentrations. As HM-3 did not inhibit proliferation of cancer cells (data not shown), the cell migration assay is an important parameter to evaluate the cellular function of HM-3. Based on the above results, HCT-116 was selected to setup an in vivo model to evaluate the activity and dose-efficacy relationship of HM-3.

On an HCT-116 xenograft model in nude mice, HM-3 inhibited HCT-116 tumor growth. Three effects may account for this inhibitory effect: inhibition of HCT-116 proliferation, affecting the generation of growth factors, e.g. VEGF that stimulates tumor angiogenesis, or a direct effect on vascular endothelial cells to inhibit angiogenesis. As has been mentioned, HM-3 had no cytotoxic effect and did not inhibit HCT-116 proliferation. In fact, acute toxicity tests in mice proved that the maximum tolerated dose of HM-3 was $1,920 \mathrm{mg} / \mathrm{kg}$ by intravenous injection, which was $>600$ times as high as the effective dose (3 mg/mg) (14). Furthermore, HM-3 seems not to decrease the expression levels of growth factors within tumor tissues (Fig. 8). Actually, sunitinib $(60 \mathrm{mg} / \mathrm{kg})$ and HM-3 (3 mg/kg) significantly increased VEGF-expressing cells within tumor tissues compared with the control group. This result is in accordance with a previous study (29) that decreased MVD within the tumor tissue (Fig. 7) caused higher levels of hypoxia in the tumor microenvironment, which resulted in upregulation of HIF-1 $\alpha$ expressions in tumor cells and thereafter higher levels of VEGF expression. However, this higher level of VEGF did not increase angiogenesis in the tumor (Fig. 7), as HM-3 directly inhibits HUVEC migration (15). Endothelial cell migration is an important part of tumor angiogenesis and HM-3 can inhibit this process. This result confirmed that cell proliferation and cell migration are two independent processes, and inhibition of endothelial cell migration is enough to efficiently inhibit angiogenesis. In contrast, once angiogenesis inhibitors are removed, the higher hypoxia state and higher levels of HIF-1 $\alpha$ and VEGF levels will restart angiogenesis in tumor tissues and tumor will soon grow again. This was often found in clinical practice (30).

After VEGF engagement of VEGFR2, the intracellular parts of VEGFR2 were tyrosine-phosphorylated that can recruit and activate intracellular guenine-nucleotide exchange factors (GEFs) and GTPase activating proteins (GAPs). They can also activate GEFs and GAPs indirectly via PI3Ks. Similarly, after integrin $\alpha v \beta 3$ activation, the intracellular parts of integrin $\alpha v \beta 3$ recruit and activate FAK-Src complex, which also recruit and activate GEFs and GAPs via 'adaptor proteins'. These GEFs and GAPs regulate the activities of RhoGTPases, which include RhoA, Rac1 and Cdc42 and are central regulators of cell migration (31). Recent research confirmed that angiogenic regulations by integrin $\alpha v \beta 3$ and VEGFR2 are not two independent events, on the contrary, they synergize with each other. After VEGFR2 is intracellular tyrosine-phosphorylated, they recruit and activate SFKs to activate (phosphorylated) the integrin $\beta 3$ subunit. $\beta 3$ phosphorylation triggers the generation of a complex of integrin $\alpha v \beta 3$ and VEGFR2, the formation of which further stimulats the phosphorylation of VEGFR2 (32-34). Antibodies of integrin $\alpha v \beta 3(35,36)$ and receptor-tyrosine kinase inhibitors (e.g. sunitinib) (37) all inhibit the complex formation, inhibit phosphorylation of intracellular parts of VEGFR2 and integrin $\beta 3$ subunit, decrease the activities of RhoGTPases and inhibit cell migration and angiogenesis (38). This working model can be used to further investigate the molecular mechanisms of the special dose-efficacy relationship of integrin antagonists and other anti-angiogenic reagents such as those targeting VEGF (e.g. avastin) or its intracellular signaling (e.g. sunitinib). The above molecular mechanistic aspects are worthy of further investigation.

\section{Acknowledgements}

The present study was supported by the Priority Academic Program Development of Jiangsu Higher Education Institutions (PAPD), the Project Program of State Key Laboratory of Natural Medicines (no. SKLNMBZ201403), and the National Science and Technology Major Projects of New Drugs (nos. 2016ZX09101121 and 2014ZX09508007) in China.

\section{References}

1. Hanahan D and Weinberg RA: Hallmarks of cancer: The next generation. Cell 144: 646-674, 2011.

2. Folkman J: Seminars in Medicine of the Beth Israel Hospital, Boston. Clinical applications of research on angiogenesis. NEngl J Med 333: 1757-1763, 1995.

3. Sharma RA, Harris AL, Dalgleish AG, Steward WP and O'Byrne KJ: Angiogenesis as a biomarker and target in cancer chemoprevention. Lancet Oncol 2: 726-732, 2001.

4. Carmeliet P and Jain RK: Angiogenesis in cancer and other diseases. Nature 407: 249-257, 2000.

5. Cai $\mathrm{W}$ and Chen $\mathrm{X}$ : Anti-angiogenic cancer therapy based on integrin alphavbeta3 antagonism. Anticancer Agents Med Chem 6: 407-428, 2006. 
6. Demetri GD, van Oosterom AT, Garrett CR, Blackstein ME, Shah MH, Verweij J, McArthur G, Judson IR, Heinrich MC, Morgan JA, et al: Efficacy and safety of sunitinib in patients with advanced gastrointestinal stromal tumour after failure of imatinib: A randomised controlled trial. Lancet 368: 1329-1338, 2006.

7. Motzer RJ, Michaelson MD, Redman BG, Hudes GR, Wilding G, Figlin RA, Ginsberg MS, Kim ST, Baum CM, DePrimo SE, et al: Activity of SU11248, a multitargeted inhibitor of vascular endothelial growth factor receptor and platelet-derived growth factor receptor, in patients with metastatic renal cell carcinoma. J Clin Oncol 24: 16-24, 2006.

8. Folkman J: Role of angiogenesis in tumor growth and metastasis. Semin Oncol 29 (Suppl 16): S15-S18, 2002.

9. Brooks PC, Clark RA and Cheresh DA: Requirement of vascular integrin alpha v beta 3 for angiogenesis. Science 264: 569-571, 1994.

10. Jin H and Varner J: Integrins: Roles in cancer development and as treatment targets. Br J Cancer 90: 561-565, 2004.

11. Kumar CC: Integrin alpha $v$ beta 3 as a therapeutic target for blocking tumor-induced angiogenesis. Curr Drug Targets 4: 123-131, 2003.

12. Liu Z, Wang $F$ and Chen $X$ : Integrin alpha(v)beta(3)-targeted cancer therapy. Drug Dev Res 69: 329-339, 2008.

13. Meerovitch K, Bergeron F, Leblond L, Grouix B, Poirier C, Bubenik M, Chan L, Gourdeau H, Bowlin T and Attardo G: A novel RGD antagonist that targets both alphavbeta3 and alpha5 beta1 induces apoptosis of angiogenic endothelial cells on type I collagen. Vascul Pharmacol 40: 77-89, 2003.

14. Zhou K, Zheng X, Xu HM, Zhang J, Chen Y, Xi T and Feng T: Studies of poly(ethylene glycol) modification of HM-3 polypeptides. Bioconjug Chem 20: 932-936, 2009.

15. Xu HM, Yin R, Chen L, Siraj S, Huang X, Wang M, Fang H and Wang Y: An RGD-modified endostatin-derived synthetic peptide shows antitumor activity in vivo. Bioconjug Chem 19: 1980-1986, 2008.

16. Xu H, Pan L, Ren Y, Yang Y, Huang X and Liu Z: RGD-modified angiogenesis inhibitor HM-3 dose: Dual function during cancer treatment. Bioconjug Chem 22: 1386-1393, 2011.

17. Reddy AB, Srivastava SK and Ramana KV: Aldose reductase inhibition prevents lipopolysaccharide-induced glucose uptake and glucose transporter 3 expression in RAW264.7 macrophages Int J Biochem Cell Biol 42: 1039-1045, 2010.

18. Liew K, Yong PV, Lim YM, Navaratnam V and Ho AS 2-Methoxy-1,4-Naphthoquinone (MNQ) suppresses the invasion and migration of a human metastatic breast cancer cell line (MDA-MB-231). Toxicol In Vitro 28: 335-339, 2014.

19. Laemmli UK: Cleavage of structural proteins during the assembly of the head of bacteriophage T4. Nature 227: 680-685, 1970.

20. Zhao C, Wang X, Zhao Y, Li Z, Lin S, Wei Y and Yang H: A novel xenograft model in zebrafish for high-resolution investigating dynamics of neovascularization in tumors. PLoS One 6 : e21768, 2011.

21. Plate KH, Breier G, Millauer B, Ullrich A and Risau W: Up-regulation of vascular endothelial growth factor and its cognate receptors in a rat glioma model of tumor angiogenesis. Cancer Res 53: 5822-5827, 1993.

22. Janouskova H, Ray AM, Noulet F, Lelong-Rebel I, Choulier L, Schaffner F,Lehmann M, Martin S, Teisinger J and Dontenwill M: Activation of p53 pathway by Nutlin-3a inhibits the expression of the therapeutic target $\alpha 5$ integrin in colon cancer cells. Cancer Lett 336: 307-318, 2013.
23. Cheong SJ, Lee CM, Kim EM, Uhm TB, Jeong HJ, Kim DW, Lim ST and Sohn MH: Evaluation of the therapeutic efficacy of a VEGFR2-blocking antibody using sodium-iodide symporter molecular imaging in a tumor xenograft model. Nucl Med Biol 38: 93-101, 2011.

24. Zhang W, Ran S, Sambade M, Huang X and Thorpe PE: A monoclonal antibody that blocks VEGF binding to VEGFR2 (KDR/Flk-1) inhibits vascular expression of Flk-1 and tumor growth in an orthotopic human breast cancer model. Angiogenesis 5: 35-44, 2002.

25. Taherian A, Li X, Liu Y and Haas TA: Differences in integrin expression and signaling within human breast cancer cells. BMC Cancer 11: 293, 2011.

26. Senger DR, Perruzzi CA, Streit M, Koteliansky VE, de Fougerolles AR and Detmar M: The alpha(1)beta(1) and alpha(2)beta(1) integrins provide critical support for vascular endothelial growth factor signaling, endothelial cell migration, and tumor angiogenesis. Am J Pathol 160: 195-204, 2002.

27. Szałek E, Karbownik A, Sobańska K, Płotek W, Grabowski T, Nowak M and Grześkowiak E: The penetration of sunitinib through the blood-brain barrier after the administration of ciprofloxacin. Acta Pol Pharm 71: 691-697, 2014.

28. Zhu B, Xu HM, Zhao L, Huang X and Zhang F: Site-specific modification of anti-angiogenesis peptide HM-3 by polyethylene glycol molecular weight of $20 \mathrm{kDa}$. J Biochem 148: 341-347, 2010.

29. Pàez-Ribes M, Allen E, Hudock J, Takeda T, Okuyama H, Viñals F, Inoue M, Bergers $G$, Hanahan D and Casanovas O: Antiangiogenic therapy elicits malignant progression of tumors to increased local invasion and distant metastasis. Cancer Cell 15: 220-231, 2009.

30. Loges S, Mazzone M, Hohensinner P and Carmeliet P: Silencing or fueling metastasis with VEGF inhibitors: Antiangiogenesis revisited. Cancer Cell 15: 167-170, 2009.

31. Ridley AJ, Schwartz MA, Burridge K, Firtel RA, Ginsberg MH, Borisy G, Parsons JT and Horwitz AR: Cell migration: Integrating signals from front to back. Science 302: 1704-1709, 2003.

32. Mahabeleshwar GH, Feng W, Reddy K, Plow EF and Byzova TV: Mechanisms of integrin-vascular endothelial growth factor receptor cross-activation in angiogenesis. Circ Res 101: 570-580, 2007.

33. Mahabeleshwar GH, Feng W, Phillips DR and Byzova TV: Integrin signaling is critical for pathological angiogenesis. J Exp Med 203: 2495-2507, 2006.

34. Mahabeleshwar GH, Chen J, Feng W, Somanath PR, Razorenova OV and Byzova TV: Integrin affinity modulation in angiogenesis. Cell Cycle 7: 335-347, 2008.

35. Byzova TV, Kim W, Midura RJ and Plow EF: Activation of integrin alpha(V)beta(3) regulates cell adhesion and migration to bone sialoprotein. Exp Cell Res 254: 299-308, 2000

36. Byzova TV, Goldman CK, Pampori N, Thomas KA, Bett A, Shattil SJ and Plow EF: A mechanism for modulation of cellular responses to VEGF: Activation of the integrins. Mol Cell 6: $851-860,2000$

37. Garrett TA, Van Buul JD and Burridge K: VEGF-induced Rac1 activation in endothelial cells is regulated by the guanine nucleotide exchange factor Vav2. Exp Cell Res 313: 3285-3297, 2007.

38. Wu J, Strawn TL, Luo M, Wang L, Li R, Ren M, Xia J, Zhang Z, Ma W, Luo T, et al: Plasminogen activator inhibitor-1 inhibits angiogenic signaling by uncoupling vascular endothelial growth factor receptor-2- $\alpha \mathrm{V} \beta 3$ integrin cross talk. Arterioscler Thromb Vasc Biol 35: 111-120, 2015. 